\title{
Pengelolaan Limbah Medis Padat Puskesmas Se-Kota Pekanbaru
}

\section{The Medical Waste Management in Health Centers as the City of Pekanbaru}

\author{
Emy Leonita, Beny Yulianto
}

\section{Program Studi Ilmu Kesehatan Masyarakat STIKes Hang Tuah Pekanbaru}

\begin{abstract}
ABSTRAK
Jumlah limbah medis yang bersumber dari fasilitas kesehatan diperkirakan semakin lama semakin meningkat. Berdasarkan Profil Kesehatan Indonesia tahun 2008, jumlah puskesmas mencapai 8.548 unit. Pengelolaan limbah medis yang berasal dari rumah sakit, puskesmas, balai pengobatan maupun laboratorium medis di Indonesia masih dibawah standar profesional. Di kota Pekanbaru tidak memiliki data yang akurat tentang pengelolaan limbah medis di puskesmas, maka dari itu dianggap perlu dilakukan penelitian terkait untuk melihat sejauh mana pengelolaan limbah medis padat puskesmas. Penelitian ini bertujuan untuk mengetahui pengelolaan limbah medis padat di Puskesmas se-Kota Pekanbaru. Jenis penelitian ini bersifat deskriptif kualitatif, penelitian ini dilakukan di 20 puskesmas yang ada di Pekanbaru. Jumlah Informan dalam penelitian ini adalah 21 orang yang terdiri dari 20 pemegang program kesehatan lingkungan masing-masing puskesmas dan 1 orang pemegang program sanitasi lingkungan di Dinas Kesehatan Kota. Instrumen penelitian menggunakan lembar observasi dan wawancara mendalam. Hasil penelitian diketahui bahwa puskesmas se kota Pekanbaru telah melakukan pengelolaan sampah padat mulai dari pemilahan, pengumpulan, penampungan, pengangkutan, namun pada tahap pemusnahan masih kurang maksimal. Kendala yang dihadapi adalah dana operasional dan tenaga maintenance yang tidak ada serta mesin insinerator yang tidak berfungsi dengan baik.
\end{abstract}

Kata Kunci : pengelolaan limbah medis, insinerator, limbah medis padat puskesmas.

\section{ABSTRACT}

The amount of medical waste comes from health facilities are expected more increasing. Based on Indonesia Health Profile 2008, amount of health centers reached 8,548 units. Management of medical waste from hospitals, health centers, clinics and medical laboratories in Indonesia is still under professional standards. In Pekanbaru city does not have accurate data on medical waste management in health centers, and therefore it necessary related research to see the extent of medical waste management health centers. This study aims to determine the medical waste management in health centers as the city of Pekanbaru. Type of research is descriptive qualitative, study was conducted in 20 health centers in Pekanbaru. The number of informants in this study were 21 people consisting of 20 holders of environmental health programs each health center and 1 holder of the environmental sanitation program at the City Health Office. Instrument research using in-depth interviews and observation sheets. Results reveal that a health center of Pekanbaru city has done a medical waste management ranging from segregation, collection, storage, transportation, yet at the stage of annihilation still less than the maximum. Constraints faced was funding the operation and maintenance personnel as well as there is no incinerator machine is not functioning properly.

Keywords : management of medical waste, incinerator, medical waste health centers

\section{PENDAHULUAN}

Fungsi Puskesmas dari dulu sampai sekarang adalah sebagai ujung tombak pelayanan kesehatan di masyarakat, karena Puskesmas langsung bersentuhan dengan masyarakat terutama di pedesaan atau masyarakat ekonomi menengah ke bawah. Bentuk pelayanan itu dapat penanganan langsung kepada pasien atau dalam tahap membuka wacana kesadaran masyarakat akan pentingnya kesehatan lingkungan. Namun aktivitas pusat layanan kesehatan kadang memunculkan persoalan baru. Sering kali Puskesmas kurang memperhatikan masalah penanganan limbah klinis yang biasanya terdiri dari bekas kain kasa, kapas, plastik, jarum suntik dan botol infus. Apalagi sekarang telah banyak Puskesmas dan klinik kesehatan swasta yang membuka layanan rawat inap dan tentu saja limbah klinis yang dihasilkan juga bertambah. Padahal limbah klinis sangatlah berbahaya karena mengandung berbagai macam jenis penyakit dan racun. Limbah klinis ini bila tidak ditangani secara baik dan benar maka fungsi atau peran dari puskesmas atau klinik kesehatan sebagai pembawa kehidupan sehat bagi masyarakat justru akan terbalik.

Pada Profil Kesehatan Indonesia tahun 2008 yang dikeluarkan Kementerian Kesehatan menyebutkan bahwa jumlah rumah sakit di Indonesia pada waktu itu mencapai 1.372 unit. Sementara itu, jumlah puskesmas mencapai 8.548 unit. Pengelolaan limbah medis yang berasal dari rumah sakit, Puskes- 
mas, balai pengobatan maupun laboratorium medis di Indonesia masih dibawah standar professional (Depkes RI, 2002). Bahkan banyak rumah sakit yang membuang dan mengolah limbah medis tidak sesuai dengan peraturan yang berlaku.

Limbah medis yang dihasilkan fasilitas kesehatan lain seperti puskesmas, belum pernah diteliti mengenai timbunan, komposisi serta pengelolaannya. Fasilitas kesehatan tersebut juga tidak melakukan inventarisasi data mengenai limbah medis yang dihasilkan sehingga sulit dalam mengidentifikasi limbah. Pengelolaan limbah yang tidak benar akan sangat membahayakan bagi petugas sarana kesehatan tersebut, dan juga bagi petugas yang menangani limbah (petugas kebersihan).

Di kota Pekanbaru memang tidak memiliki data yang akurat tentang pengelolaan limbah medis di puskesmas, maka dari itu dianggap perlu dilakukan penelitian terkait untuk mengetahui sejauh mana pengelolaan terhadap limbah medis puskesmas tersebut. Penelitian ini bertujuan untuk mengetahui pelaksanaan pengelolaan limbah medis padat di Puskesmas se-Kota Pekanbaru.

\section{METODE}

Penelitian yang dilakukan bersifat deskriptif kualitatif. Lokasi penelitian dilakukan di seluruh Puskesmas yang ada di Pekanbaru yang berjumlah 20 puskesmas. Penelitian ini dilakukan pada bulan Februari sampai dengan April 2012. Subjek penelitian ini berjumlah 21 sampel terdiri dari 20 orang pemegang program sanitasi lingkungan di setiap Puskesmas se-kota Pekanbaru dan 1 orang pemegang program sanitasi lingkungan di Dinas Kesehatan Kota Pekanbaru. Pengumpulan data dilakukan dengan wawancara mendalam dan lembar observasi, analisis data menggunakan triangulasi data. Data yang dikumpulkan yaitu proses pemilahan, pengumpulan, pengangkutan, penampungan dan pemusnahan limbah medis padat puskesmas Se Kota Pekanbaru.

\section{HASIL}

Di kota Pekanbaru terdapat 20 Puskesmas yang terdiri dari 15 Puskesmas Rawat jalan dan 5 puskesmas rawat inap. Dari tabel 1 dapat diketahui bahwa informan dalam penelitian ini sebagian besar adalah sanitarian mulai dari tingkat pendidikan D3 dan S1 kesehatan Lingkungan, hanya beberapa informan dalam penelitian adalah dokter (kepala puskesmas).

\section{Pengelolaan Limbah Medis Padat Se Kota Pekanbaru}

Berdasarkan tabel 2 dapat diketahui bahwa Pengelolaan mulai dari pemilahan, pengumpulan, penampungan dan pengangkutan berjalan dengan baik, namun pada proses pemusnahan terjadi permasalahan yaitu hanya 4 puskesmas yang melakukan pemusnahan sedangkan puskesmas lainnya melakukan sistem penyimpanan maupun membakar sendiri limbah medis yang dapat dibakar walaupun hasil yang dicapai kurang maksimal. Dari 4 puskesmas yang memiliki mesin insinerator, kondisi mesin dalam keadaan rusak/ tidak berjalan dengan baik.

\section{Proses Pemilahan}

Tahap pemilahan limbah medis telah dilakukan oleh seluruh puskesmas walaupun pada pelaksanaannya masih ada petugas kesehatan yang mencampurkan antara limbah medis dan non medis. Hal ini dikarenakan adanya sikap tidak peduli oleh pihak petugas kesehatan serta terkadang banyaknya melayani pasien sehingga petugas kesehatan tidak lagi memperhatikan limbah medis yang dihasilkan. Hal ini diakui oleh beberapa pemegang program kesehatan lingkungan dibeberapa puskesmas yang akan menjadi masalah saat akan dilakukan pengumpulan dan pemusnahan. Berikut hasil kutipan dari salah satu informan :

“......Proses pemilahan sudah kita lakukan, namun terkadang di lapangan masih ada tenaga kesehatan yang mencampurkan limbah medis dan non medis ke dalam tempat yang sudah kita sediakan (Informan 1)....".

“....Proses pemilahan sudah kita lakukan, kita sudah memberikan label-label untuk masingmasing limbah baik limbah medis dan non medis (Informan 2)....".

\section{Proses Pengumpulan}

Tahap yang kedua yaitu pengumpulan, pada tahap ini sudah seluruhnya di Puskesmas se Kota Pekanbaru telah melakukan pengumpulan limbah medis. Pengumpulan limbah medis dan non medis dikumpulkan menggunakan wadah ember plastik yang menggunakan tutup, dan safety box. Pengumpulan limbah medis dilakukan dengan cara mengambil limbah dari proses pemilahan selanjutnya dikumpulkan dalam suatu wadah besar serta tahan terhadap benda tajam yang selanjutnya diberikan label menjadi limbah medis dan non medis.

\section{Proses Penampungan}

Dari hasil observasi di lapangan, pihak puskesmas mengumpulkan terlebih dahulu semua limbah medis dan non medis ke dalam suatu wadah tertutup, apabila wadah tersebut sudah penuh setelah itu pihak puskesmas akan melakukan tahap selanjutnya yaitu penampungan. Dari hasil observasi, didapat masih ada beberapa puskemas yang menumpuk limbah medis di sekitar puskesmas yang apabila tidak dikontrol dapat dijangkau oleh pasien/masyarakat yang berkunjung ke puskesmas. 


\section{Proses Pengangkutan}

Pada tahap ini peneliti tidak mendapatkan hasil observasi dikarenakan jadwal pengangkutan limbah medis tidak bertepatan dengan kunjungan peneliti ke lapangan, namun dari hasil wawancara yang dilakukan bahwa pengangkutan limbah medis dilakukan menggunakan mobil ambulance serta kendaraan pribadi dan akan diangkut apabila limbah medis sudah penuh. Berikut kutipan wawancara dengan salah satu informan :

“......Kami menggunakan mobil ambulance untuk mengangkut limbah medis ke tempat pembakaran. Mobil ambulance terpaksa kami gunakan dikarenakan tidak adanya mobil khsusus yang disediakan untuk mengangkut limbah medis tersebut dan kami akan angkut apabila limbah sudah penuh (Informan 3)....".

\section{Proses Pemusnahan/Pembakaran}

Tahap yang kelima adalah pemusnahan dan pembakaran akhir, 4 puskesmas melakukan pemusnahan di puskesmas sendiri sedangkan 16 puskesmas melakukan pemusnahan di tempat lain yaitu Puskesmas Sidomulyo Rawat Inap dan Simpang Tiga, namun pada saat observasi bahwa insinerator yang ada pada 4 puskesmas dalam kondisi rusak yaitu proses kerja yang tidak sempurna seperti masih terdapat limbah yang tidak hancur dan tercecer di sekitar pembakaran.

Tabel 1

Karakteristik Informan Puskesmas Se Kota Pekanbaru tahun 2012

\begin{tabular}{llcc}
\hline No & Kode Informan & Jabatan & Pendidikan \\
\hline $\mathbf{1 .}$ & ST (Simpang Tiga) & Sanitarian & D-III Kesling \\
\hline $\mathbf{2 .}$ & S-RI (Sd. Rawat Inap) & Sanitarian & D-III Kesling \\
\hline 3. & S-RJ (Sd. Rawat Jalan) & Sanitarian & D-III Kesling \\
\hline $\mathbf{4 .}$ & SL (Sail) & Sanitarian & S1 Kesling \\
\hline $\mathbf{5 .}$ & RJ (Rejosari) & Ka. Pus & S1 Dokter \\
\hline $\mathbf{6 .}$ & HR (Harapan Raya) & Sanitarian & D-III Kesling \\
\hline $\mathbf{7 .}$ & MR (Melur) & Ka. Pus & S1 Dokter Gigi \\
\hline $\mathbf{8 .}$ & US (Umban Sari) & Ka. Pus & S1 Dokter \\
\hline $\mathbf{9 .}$ & RB (Rumbai Bukit) & Sanitarian & D-III Kesling \\
\hline $\mathbf{1 0}$. & SP (Senapelan) & Sanitarian & D-III Kesling \\
\hline $\mathbf{1 1 .}$ & MF (Muara Fajar) & Ka. Pus & S1 Dokter \\
\hline $\mathbf{1 2 .}$ & RU (Rumbai) & Ka. Pus & S1 Dokter \\
\hline $\mathbf{1 3 .}$ & KW (Karya Wanita) & Ka. Pus & S1 Dokter \\
\hline $\mathbf{1 4 .}$ & LS (Langsat) & Ka. Pus & S1 Dokter \\
\hline $\mathbf{1 5 .}$ & TR (Tenayan Raya) & Sanitarian & D-III Kesling \\
\hline $\mathbf{1 6 .}$ & LP (Lima Puluh) & Sanitarian & S1 Kesling \\
\hline $\mathbf{1 7 .}$ & SB (Simpang Baru) & Sanitarian & D-III Kesling \\
\hline $\mathbf{1 8 .}$ & PS (Payung Sekaki) & Ka. Pus & S1 Dokter \\
\hline $\mathbf{1 9}$ & GD (Garuda) & Sanitarian & S1 Kesling \\
\hline $\mathbf{2 0 .}$ & PK (Pekanbaru Kota) & Sanitarian & S1 Kesling \\
\hline & & &
\end{tabular}

Tabel 2

Pengelolaan Limbah Medis Padat Se-Kota Pekanbaru

\begin{tabular}{|c|c|c|c|c|c|c|c|c|}
\hline \multirow[t]{2}{*}{ No } & \multirow[t]{2}{*}{ Puskesmas } & \multicolumn{5}{|c|}{ Pengelolaan Limbah Medis Padat } & \multirow{2}{*}{$\begin{array}{l}\text { Kepemilikan } \\
\text { Insinerator }\end{array}$} & \multirow[t]{2}{*}{ Kondisi } \\
\hline & & $\begin{array}{l}\text { Pemilah } \\
\text { an }\end{array}$ & $\begin{array}{l}\text { Pengum } \\
\text { pulan }\end{array}$ & $\begin{array}{l}\text { Penampun } \\
\text { gan }\end{array}$ & $\begin{array}{l}\text { Pengangku } \\
\text { tan }\end{array}$ & $\begin{array}{l}\text { Pemusna } \\
\text { han }\end{array}$ & & \\
\hline 1. & Langsat & Ada & Ada & Ada & Ada & Tidak ada & Tidak ada & \\
\hline 2. & RI Sidomulyo & Ada & Ada & Ada & Ada & Ada & Ada & Rusak \\
\hline 3. & Rumbai Bukit & Ada & Ada & Ada & Ada & Tidak ada & Tidak ada & \\
\hline 4. & RJ Sidomulyo & Ada & Ada & Ada & Ada & Tidak ada & Tidak ada & \\
\hline 5. & Senapelan & Ada & Ada & Ada & Ada & Tidak ada & Tidak ada & \\
\hline 6. & Melur & Ada & Ada & Ada & Ada & Tidak ada & Tidak ada & \\
\hline 7. & Sail & Ada & Ada & Ada & Ada & Tidak ada & Tidak ada & \\
\hline 8. & Simpang Tiga & Ada & Ada & Ada & Ada & Ada & Ada & Rusak \\
\hline 9. & Garuda & Ada & Ada & Ada & Ada & Ada & Ada & Rusak \\
\hline 10. & Rumbai & Ada & Ada & Ada & Ada & Tidak ada & Tidak ada & \\
\hline 11. & Karya Wanita & Ada & Ada & Ada & Ada & Tidak ada & Tidak ada & \\
\hline 12. & Simpang Baru & Ada & Ada & Ada & Ada & Tidak ada & Tidak ada & \\
\hline 13. & Muara Fajar & Ada & Ada & Ada & Ada & Tidak ada & Tidak ada & \\
\hline 14. & Payung Sekaki & Ada & Ada & Ada & Ada & Tidak ada & Tidak ada & \\
\hline 15. & Tenayan Raya & Ada & Ada & Ada & Ada & Tidak ada & Tidak ada & \\
\hline 16. & Lima Puluh & Ada & Ada & Ada & Ada & Ada & Ada & Rusak \\
\hline 17. & Pekanbaru Kota & Ada & Ada & Ada & Ada & Tidak ada & Tidak ada & \\
\hline 18. & Harapan Raya & Ada & Ada & Ada & Ada & Tidak ada & Tidak ada & \\
\hline 19. & Rejosari & Ada & Ada & Ada & Ada & Tidak ada & Tidak ada & \\
\hline 20. & Umban Sari & Ada & Ada & Ada & Ada & Tidak ada & Tidak ada & \\
\hline
\end{tabular}




\section{PEMBAHASAN}

\section{Proses Pemilahan}

Sistem pemilahan dilakukan berdasarkan limbah medis dan non medis, tempat limbah diberikan label-label sehingga petugas tahu akan membuang limbah berdasarkan jenisnya. Hasil observasi di lapangan tempat limbah medis terdiri dari tempat limbah plastik biasa untuk bekas perban, kapas dan safety box untuk bekas jarum suntik. Proses pemilahan dilakukan untuk mempermudah petugas kesehatan untuk menangani limbah-limbah yang dihasilkan sehingga untuk proses/tahap selanjutnya akan menjadi lebih mudah. Pemilahan merupakan proses pertama dalam pengelolaan limbah puskesmas. Dengan proses pemilahan tersebut diharapkan adanya kategori/klasifikasi limbah yang dihasilkan oleh puskesmas sehingga mempermudah tenaga sanitarian untuk melanjutkan ke tahap selanjutnya.

Proses pemilahan untuk masing-masing puskesmas telah sesuai dengan Permenkes RI 1204/MENKES/SK/X/2004 yaitu proses pemilahan dilakukan dari sumber serta dipisahkan antara limbah medis dan non medis. Berdasarkan Permenkes RI 1204/MENKES/SK/X/2004 seharusnya limbah puskesmas dipisahkan menurut limbah infeksius, patologi, farmasi, benda tajam, sitotoksis.

Penelitian ini sejalan dengan penelitian yang dilakukan oleh Al-Emad (2011) di rumah sakit Yaman. Pada penelitian tersebut diketahui bahwa 12 rumah sakit yang ada di Rumah Sakit Yaman melakukan proses pemilahan terhadap limbah medis dan non medis.

\section{Proses Pengumpulan}

Berdasarkan hasil observasi semua limbah padat medis dicampurkan dengan berbagai limbah padat medis lainnya, sementara limbah tajam seperti bekas suntikan dikumpulkan menggunakan safety box. Hal ini sesuai dengan Permenkes RI 1204/MENKES/SK/X/2004 tentang persyaratan kesehatan lingkungan rumah sakit yaitu benda tajam sebaiknya ditampung menggunakan safety box atau terbuat dari bahan yang kuat. Penggunaan bahan yang kuat dalam pengumpulan digunakan agar benda tajam tidak dapat menembus kebagian luar karena apabila benda tajam seperti jarum suntik menembus tempat pengumpulan tentunya akan menyebabkan tertusuk kepada tenaga kesehatan yang menangani limbah medis tersebut.

\section{Proses Penampungan}

Dari hasil observasi di lapangan, pihak puskesmas mengumpulkan terlebih dahulu semua limbah medis dan non medis ke dalam suatu wadah tertutup, apabila wadah tersebut sudah penuh setelah itu pihak puskesmas akan melakukan tahap selanjutnya yaitu penampungan. Dari hasil observasi, didapat masih ada beberapa puskemas yang menumpuk limbah medis di sekitar puskesmas yang apabila tidak dikontrol dapat dijangkau oleh pasien/masyarakat yang berkunjung ke puskesmas

Hasil observasi di atas menunjukkan salah satu puskesmas menampung limbah medis berdekatan dengan toilet umum, hal ini tentunya dapat membahayakan pasien yang berobat ke puskesmas, apabila ada pengunjung anak-anak dan tidak tertutup kemungkinan limbah medis tersebut akan diambil. Namun ada juga puskesmas yang menampung limbah medis dan non medis di tempat yang tidak dapat dijangkau oleh masyarakat/ pasien yang akan berobat ke puskesmas.

Menurut Chandra (2006), tempat penampungan limbah dibagi menurut kategorinya, baik plastik pembungkus maupun wadah penampungan limbah. Wadah limbah dan plastik hitam diletakkan di kantor, unit pelayanan, unit gizi dan instalasi lain. Untuk limbah klinis seperti limbah infeksius kantong penampungannya bewarna kuning dilengkapi dengan simbol biohazard. Pada penelitian ini penggunaan plastik kuning dengan simbol biohazard tidak dilakukan. Penelitian ini sejalan dengan penelitian yang dilakukan oleh Kabir et all (2004), dimana hasil penelitian tersebut mengatakan beberapa rumah sakit di Iran tidak menggunakan plastik warna kuning limbah infeksi.

Berdasarkan Permenkes RI 1204/MENKES/SK/X/2004, penampungan sementara selambat-lambatnya dilakukan selama 24 jam bagi yang mempunyai insinerator, namun apabila tidak memiliki mesin insinerator maka bekerja sama dengan rumah sakit lain dan pemusnahan selambat-lambatnya 24 jam apabila disimpan pada suhu ruang. Namun pada penelitian ini, berdasarkan hasil observasi limbah medis padat disimpan pada waktu yang cukup lama antara 1 minggu sampai 3 bulan. Hal ini tentunya bertentangan dengan Permenkes RI 1204/MENKES/SK/X/2004 yang menetapkan penampungan sementara selambat-lambatnya dilakukan selama 24 jam.

\section{Proses Pengangkutan}

Pada tahap ini tidak mendapatkan hasil observasi dikarenakan jadwal pengangkutan limbah medis tidak bertepatan dengan kunjungan peneliti ke lapangan, namun dari hasil wawancara yang dilakukan bahwa pengangkutan limbah medis dilakukan menggunakan mobil ambulance serta kendaraan pribadi dan akan diangkut apabila limbah medis sudah penuh. Bila mobil ambulance tidak steril maka ada kemungkinan untuk terjadi perpindahan kuman penyakit kepada pasien.

Menurut Chandra (2006), kendaraan yang dipakai harus memenuhi syarat dalam hal kemudahan pemakaian dan pembersihannya, selain dilengkapi juga 
dengan alat pengumpul kebocoran. Dalam kendaraan pengangkut limbah, ruang supir secara fisik harus terpisah dari ruang limbah. Bila dilihat dari persyaratan di atas, tentunya menggunakan ambulance dan kendaraan pribadi sebagai pengangkut limbah medis tidak direkomendasikan karena mobil pribadi tidak memiliki pembatas antara supir dan limbah medis, sedangkan ambulance tidak memiliki syarat pengumpul kebocoran serta ambulance merupakan kendaraan yang digunakan untuk membawa pasien bukan membawa limbah medis.

\section{Proses pemusnahan/pembakaran}

Tahap yang kelima adalah pemusnahan dan pembakaran akhir, 4 puskesmas melakukan pemusnahan di puskesmas sendiri sedangkan 16 puskesmas melakukan pemusnahan di tempat lain yaitu Puskesmas Sidomulyo Rawat Inap dan Simpang Tiga, namun pada saat observasi bahwa insinerator yang ada pada 4 puskesmas dalam kondisi rusak yaitu proses kerja yang tidak sempurna seperti masih terdapat limbah yang tidak hancur dan tercecer di sekitar pembakaran.

Sebenarnya kondisi ini sangat memprihatinkan, dimana jika limbah medis dan non medis tersebut tidak dikelola dengan baik maka akan menimbulkan masalah baik untuk pihak puskesmas maupun masyarakat yang ada disekitar puskesmas. Tentunya ini harus menjadi perhatian dan catatan penting bagi pihak terkait seperti Dinas Kesehatan Kota dan pemegang kebijakan untuk lebih memperhatikan semua wilayah kerja puskesmas dalam mengelola limbah medis dan non medis yang dihasilkan oleh puskesmas karena puskesmas merupakan ujung tombak pelayanan dasar dalam masyarakat yang harus memberikan pelayanan dan contoh yang baik kepada semua pihak terutama masyarakat.

Berdasarkan Permenkes RI 1204/MENKES/SK/X/2004, limbah medis harus dibakar menggunakan insinerator dengan suhu 1000$1200^{\circ} \mathrm{C}$. Namun pada penelitian ini, pembakaran yang dilakukan oleh pihak puskesmas tidak sampai pada suhu $1000-1200^{\circ} \mathrm{C}$, hal ini terlihat dari masih utuhnya jarum suntik sehingga masih dapat membahayakan orang lain bila tercecer. Diperkirakan suhu insinerator pada puskesmas hanya $800^{\circ} \mathrm{C}$.

\section{KESIMPULAN}

Pengelolaan limbah medis padat puskesmas se kota Pekanbaru telah dilakukan mulai dari tahap pemilahan, pengumpulan, penampungan dan pengangkutan, namun pada tahap pemusnahan masih kurang maksimal karena pembakaran yang dilakukan masih menyisakan bentuk utuh seperti jarum suntik.

\section{SARAN}

Diharapkan Dinas Kesehatan Kota lebih memperhatikan proses penampungan, pengangkutan dan pemusnahan serta menambah tenaga teknis dalam pemeliharaan alat insenerator.

\section{UCAPAN TERIMA KASIH}

Ucapan terima kasih diajukan kepada Kepala Dinas Kesehatan Kota Pekanbaru Pemegang Sanitasi dan Kepala Puskesmas Se Kota Pekanbaru yang telah membantu penelitian ini.

\section{DAFTAR PUSTAKA}

Achmadi, U. 2008, Horison Baru Kesehatan Masyarakat di indonesia, Rienika Cipta. Jakarta.

Askarian, M. 2004. Hospital Waste Management Status In University Hospitals of The Fars

Province, Iran. International Journal of Environmental Health Research, ISSN 09603123.

Chandra, B. 2007. Pengantar Kesehatan Lingkungan, Jakarta : EGC.

Departemen Kesehatan RI, 2002. Pedoman Sanitasi Rumah Sakit Di Indonesia. Dirjen PPM \& PL Depkes RI, Jakarta.

Departemen Kesehatan RI, (2004) Keputusan Menteri Kesehatan RI Nomor 1204/Menkes/SK/X/2004 tentang Persyaratan Kesehatan Lingkungan Rumah Sakit, Dirjen PPM dan PL, Depkes RI, Jakarta.

Emad, A. 2011. Assessment Of Medical Waste Management In The Main Hospital In Yemen. Eastern Mediterranean Health Journal, Vol. 17 No. 10.

Erryliani, 2010. Laporan Observasi Tentang Limbah Puskesmas di Puskesmas Blok A. Kabupaten Tanah Lembu.

Ichsan, S. Pelatihan Pengelolaan Limbah medis. http://sanitasisurveilans.blogspot.com. Diakses 26 Februari 2012.

Jais, A. 2009. Pengelolaan Limbah Medis Rumah Sakit.http://uwityangyoyo.wordpress.com.

Diakses tanggal 14 Februari 2012.

Keputusan Kepala Bapedal Nomor Kep03/Bapedal/09/1995 Tahun 1995 tentang Persyaratan Teknis Pengelolaan Limbah B3.

Undang-Undang Republik Indonesia Nomor 32 Tahun 2009. Tentang Perlindungan dan Pengelolaan Lingkungan Hidup.

Departemen Kesehatan, 2008. Profil Kesehatan Indonesia 